\title{
DEVELOPMENT OF ELECTRONIC PETITION TOOLS IN UKRAINE BASED ON INTERNATIONAL EXPERIENCE
}

Keywords: e-democracy, e-democracy tools, e-appeals, e-petitions, organizational and legal mechanism.

ABSTRACT: The purpose of the article is to analyze the public administration mechanisms of electronic petitions (e-petitions), scientific and theoretical justification of recommendations to Ukrainian authorities on their improvement.

The paper analyzes the approaches to defining the essence of the concepts of individual and collective e-petitions.

The mechanisms of e-appeals (e-petitions) at the national and local levels have been studied. A comparison of the mechanisms of formation and submission of e-petitions in the Ukrainian legislation has been made.

It is proposed to improve the interaction of national and local levels by redirecting petitions from local authorities to national executive bodies.

The main shortcomings of the existing mechanism of public administration of e-petitions at the national level have been identified. In the process of analyzing the shortcomings of the organizational and legal mechanism, foreign experience and its possibility use in Ukraine were taken into account. Considering the identified shortcomings should further increase the level of civil society involvement in public administration of public affairs and, as a consequence, accelerate the democratization of Ukrainian society and Ukraine as a full member of the European community.

1 Ph.D. in Technical Science, Doctoral Student at the Department of the Parliamentary and Political Management, National Academy for Public Administration under the President of Ukraine, yan.yansons@gmail.com. ORCID: 0000-0002-9161-1493. 
In order to assess the level of availability of the electronic individual petitions tool, a study of the official web resources of central and local executive bodies was conducted and ways to improve the practical implementation of the e-petition tool in order to increase its accessibility were identified.

The main identified shortcomings are: staffing issues (personnel quality); accessibility and transparency of e-democracy tools for citizens; lack of a unified approach to the implementation of e-appeals (petitions); lack of bottom-up redirection mechanisms; low civil society awareness of public authorities' responsibilities and powers; lack of mechanisms for imperative execution of e-petitions, etc.

Based on the analysis of international experience of implementation of e-appeals (e-petitions), the ways to improve national legislation have been proposed and the recommendations for central authorities, local governments and civil society organizations have been developed to improve the organizational and legal mechanism of public administration of e-democracy tools (electronic individual and collective petitions). The main ones are as follows: amendments to a number of legislative acts, including the conceptual and strategic level; taking into account the imperative implementation of e-petitions; actualization of the issue of administrative and criminal liability for non-compliance with the requirements of the legislation regarding the implementation of e-petitions.

\section{INTRODUCTION}

Ukraine has chosen the path of creating a democratic society and enshrined it in the main law of the country - the Constitution.

The emergence of e-democracy, as a consequence of the development of information and communication technologies (ICT), has affected the ability of citizens to take socio-political part in public administration. This civil society participation transforms public communications and creates a new system of relations between citizens and authorities through the creation and application of e-democracy tools. The implementation of e-democracy tools in the framework of the Government's tasks to digitize 
the population of Ukraine is of positive importance for building a democratic state. At the same time, attention should be focused not only on technical aspects. Thus, the international experience of implementing e-democracy tools shows the importance of mechanisms for their implementation.

One of the problems with the introduction of e-democracy tools is the unpreparedness of public servants and the civil society to use them. The analysis of appeals and petitions reflects the lack of citizens' understanding of their rights, duties and responsibilities of the authorities and their representatives. On the other hand, some subjects of power believe that excessive civil society involvement in the country's political life is an attempt to limit their rights as authorities.

The effectiveness of e-democracy depends on the joint work of government, civil society and international experts.

Despite positive developments in the formation and implementation of certain elements of e-democracy in Ukraine, the mechanisms of its development, the introduction of e-tools, the results of the analysis of the current situation and the identified shortcomings highlight the need to increase its efficiency. According to the author, one of the ways to ensure the development of e-democracy is to improve its mechanisms, primarily organizational and legal ones.

The purpose of the article is to study the implementation and application of e-petition tools in Ukraine and the leading democratic countries of the world, generalize the best practices in this area and provide a scientific and theoretical basis for recommendations to the Ukrainian authorities for their improvement.

\section{E-PETITIONS LEGISLATIVE BASIS}

One of the areas of e-democracy is to increase civil society participation in state-building processes. This is ensured by granting the right to citizens to participate in the processes of state building and local governance.

In the exercise of the right to civil society participation in political processes at national, regional and local levels, the European Union mem- 
ber states use their own regulations, which include the Council of Europe's Convention on the Participation of Foreigners in Public Life at Local Level of 05 November 1992 (Convention on the Participation of Foreigners in Public Life at Local Level. 1992), Recommendation CM/Rec (2001)19 “On Citizens' Participation in Local Public Life" (Recommendation Rec (2001)19 of the Committee of Ministers, 2001), The Code of Good Practice for Civil Participation of 2009 (Code of good practice for civil participation, 2009) and others. In addition, the concept paper of the Recommendations of the Committee of Ministers of the Council of Europe of 2009 serves a "roadmap" for the development of e-democracy, and Annex 1 to the Recommendations contains a list of basic e-democracy tools.

The Concept of e-democracy development in Ukraine states that "the most common e-democracy tools currently used in Ukraine at both national and local levels are e-appeals, e-petitions, e-consultations, participation budgets (public budgets)" (Concept of e-democracy development in Ukraine, 2017). According to the Recommendations of the Committee of Ministers of the Council of Europe, the most identical term to an e-appeal is an "E-Petition", which serves to electronically delivery a protest or recommendation to a democratic institution regarding a public institution, law or to provide to public authorities or representatives the citizen's ideas: "By forming and signing applications, they can take part in discussing an important public topic online. E-appeals can take various forms, aimed to facilitate citizens' contact with public authorities and other democratic institutions, and to stimulate public discussion." (Concept of e-democracy development in Ukraine, 2017).

The Concept emphasizes the importance of creating resources to publish datasets in the form of open data, including through electronic platforms such as Civil Society and Government, Smart City or Unified System of Local Petitions which combine several electronic participation tools."

In general, the purpose of these tools is to create conditions for transparent activities and access to public authorities, which in turn allows citizens to freely use open information, appeal to public authorities and local governments on important issues, and to monitor their implementation. 
According to the Concept of e-democracy development in Ukraine (2017), "an e-appeal is a written appeal sent via Internet, electronic means of communication" (Concept of e-democracy development in Ukraine, 2017).

A variant of a collective e-appeal is an e-petition, which is defined as a collective e-appeal shaped as a text of complaint (protest) and/or proposal, to which the addressee (a subject of authority) publicly announces its position of consent or dissent regarding the petition, provides arguments in case of disagreement and organizes joint work with the authors and their supporters to elaborate and implement the plan of petition's implementation in case of consent" (Concept of e-democracy development in Ukraine, 2017).

At the national level, the legal grounds for the use of e-appeals and petitions are the Laws of Ukraine “On Citizens' Appeals" № 394/96-VR of 02 October 1996 (as amended) (On Citizens' Appeals, 1996) and "On Access to Public Information” № 2939-VI of 13 January 2011 (as amended) (On access to public information, 2011). A number of normative legal acts specify and concretize the activities of higher state bodies in terms of the use of e-appeals (e-petitions), namely:

Decree of the President of Ukraine № 523/2015 “On the procedure for consideration of an e-petition addressed to the President of Ukraine" of 28 August 2015;

Order of the Chairman of the Verkhovna Rada [Parliament] of Ukraine №1494 "On some issues of organization of work on registration and support of e-petitions addressed to the Verkhovna Rada of Ukraine" of 28 October 2015 (as amended);

Resolution of the Cabinet of Ministers of Ukraine № 457 “On approval of the Procedure for consideration of an e-petition addressed to the Cabinet of Ministers of Ukraine" of 22 July 2016.

\section{MECHANISM OF E-PETITIONS}

According to the Law of Ukraine "On Amendments to the Law of Ukraine “"On Citizens’ Appeals" regarding e-appeals and e-petitions” № 577-VIII of 02 July 2015 (as amended), citizens have the opportunity to 
apply on personal matters to public authorities, local governments, associations of citizens, enterprises, institutions, organizations, regardless of ownership, media, officials, etc. At the same time, a collective e-appeal (e-petition) can be submitted only to the President of Ukraine, the Verkhovna Rada of Ukraine, the Cabinet of Ministers of Ukraine, and a local self-government body.

The ways in which e-appeals and e-petitions are submitted also differ. Appeals may be submitted via e-mail or other means, and petitions only through the official website of a body to which it is addressed, or through the website of a civil society organization (CSO) that collects signatures in support of e-petition.

Unlike appeals, which, if properly submitted, should be considered by relevant officials, petitions are considered by the President of Ukraine, the Verkhovna Rada of Ukraine, the Cabinet of Ministers of Ukraine only when they gather 25,000 signatures within three months from the date of publication.

Petitions to local governments should collect the number of signatures depending on the number of inhabitants in a relevant administrativeterritorial unit.

The support or non-support of an e-petition is publicly announced on the official website of the President of Ukraine - regarding an e-petition addressed to the President of Ukraine, by the Chairman of the Verkhovna Rada of Ukraine - regarding an e-petition addressed to the Verkhovna Rada of Ukraine, by the Prime Minister of Ukraine - regarding an e-petition addressed to the Cabinet of Ministers of Ukraine, by the chairman of a relevant local council - regarding an e-petition addressed to a local government body.

Figure 1 shows a diagram of the mechanism for the implementation of e-petitions in Ukraine.

This mechanism provides for the redirection of e-appeals (e-petitions) by the highest state authorities to relevant subordinate structures in the form of orders, acts, etc. At the same time, there is no reverse mechanism for sending received e-appeals (e-petitions) from subordinate public authorities to higher public authorities. The author proposes to introduce a procedure that should also ensure the possibility of redirecting e-appeals 


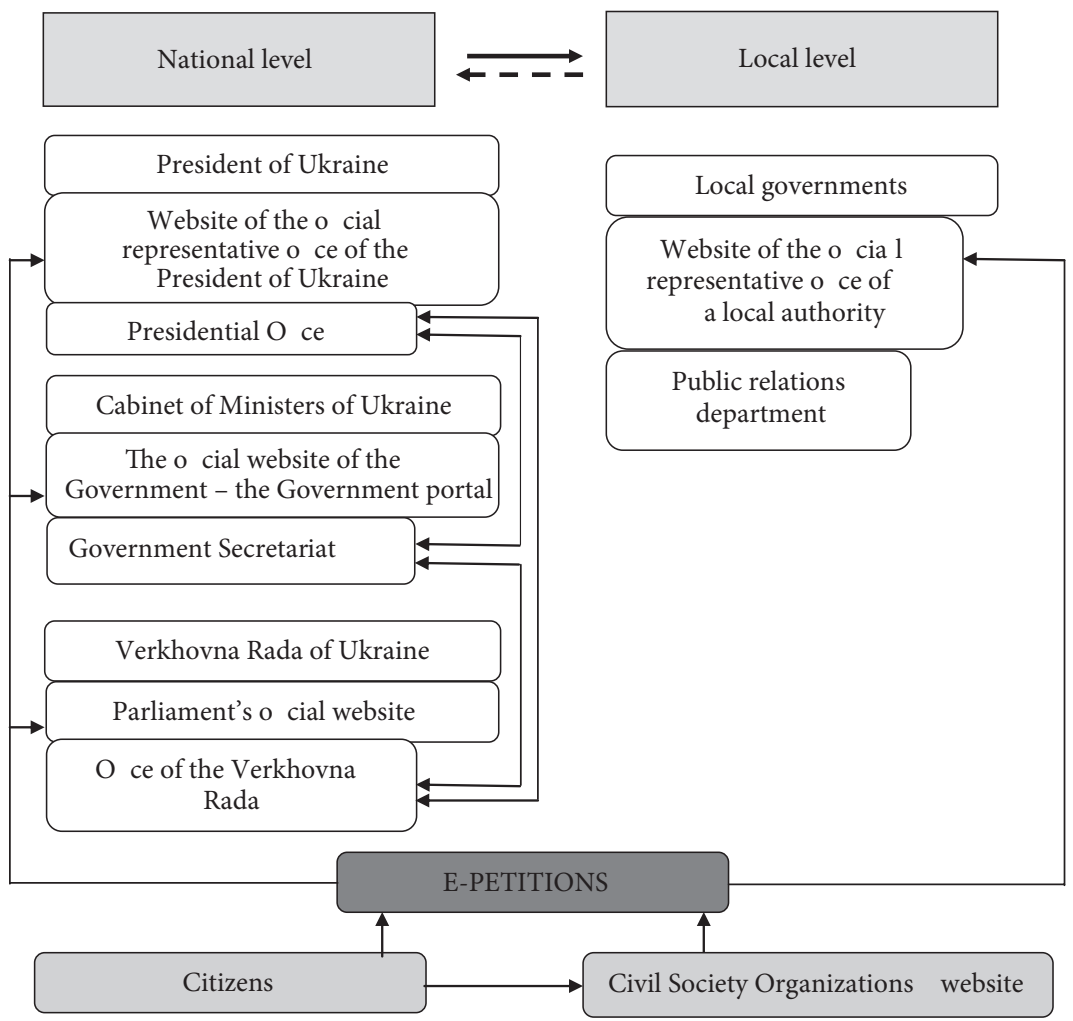

Fig. 1. Scheme of the mechanism of public administration the e-petitions' tool Source: developed by the author

(e-petitions) from local self-government bodies to higher-level public authorities (President of Ukraine, Cabinet of Ministers of Ukraine, Verkhovna Rada of Ukraine), subject to compliance with local requirements on which the e-appeals (e-petitions) were filed.

The algorithm for implementing the "bottom-up" e-petition redirection procedure should include the following procedures:

- after the completion of the procedure of gathering a sufficient number of signatures, an e-petition is submitted to a local selfgovernment body (LSB); 
- in response to e-petition, certain LSB officials indicate that it can be redirected to a public authority responsible for issues raised in the e-petition;

- with the consent of the initiator of an e-petition, LSB representatives initiate the redirection of an e-petition to a higher state authority;

- while redirecting an e-petition "bottom-up", LSB must properly justify the grounds for redirection and confirm the number of signatures already gathered in support of the e-petition;

- in case a petition is accepted by a higher public authority for further gathering of signatures in support of it, the previously gathered signatures must be taken into account.

Another disadvantage of the existing system of e-appeals (e-petitions) is their advisory nature.

While it is imperative to respond to a e-petition in the form of a reply, the implementation of a e-petition is not in fact de jure imperative.

Analysis of foreign experience and its possible e-appeal in Ukraine allows us to put forward the following proposals to improve the tool of e-appeals (e-petitions).

Thus, a clear example of the imperativeness of e-petitions is the United Kingdom, Latvia and Finland (The UK Parliament petitions website (e-petitions), 2020). E.g., in Finland, an e-petition supported by 50,000 citizens becomes a bill (The official website of Finland's petitions, 2020). In Latvia, if a petition has received 10,000 signatures, it has to be considered by the Parliament (Official web-site of the Latvian public organization "ManaBalss", 2020). The population of Finland is 5.5 million. The mentioned number of signatures is $1 \%$ of the population. In Latvia $-0.5 \%$. So, for Ukraine with a population of 40 million citizens, the figures will be different, 400 thousand in the event of $1 \%$ and 200 thousand - at $0.5 \%$. The imperativeness of e-petitions in Ukraine can improve public attitude towards e-democracy tools.

The disproportion in the number of petitions to higher authorities in Ukraine is worth noting. E.g., as of mid-September 2020, the official website of the President of Ukraine was gathering signatures for 2,420 petitions (Official web-site of The President of Ukraine, 2020), the Government 
portal - 115 petitions (Official site of The Cabinet of Ministers of Ukraine, 2020), the portal of the Verkhovna Rada of Ukraine - 86 petitions (Official site of The Verkhovna Rada of Ukraine, 2020). This reflects that the petitions' initiators do not understand powers, functions and division of responsibilities between the President of Ukraine, the Cabinet of Ministers of Ukraine and the Verkhovna Rada of Ukraine. The lack of this knowledge combined with legally incorrect wording ultimately reduces the effectiveness of this electronic tool.

To solve the problem of inefficient use of the tool of e-appeals (e-petitions), a comprehensive mechanism should be applied which combines long-term measures and current activities. Long-term measures should be aimed at forming a basic education system in Ukraine in relation to basics and principles of public authorities and local self-government. These bodies should pursue an information policy to clarify their functional duties, areas of responsibility, etc. Ongoing measures should provide assistance to applicants regarding the correctness of the form and the correct choice of addressees for appeals (petitions). These measures can be implemented by introducing new positions in higher government bodies with proper functional duties or by expanding the responsibilities of existing staff.

At present, Ukrainian society has a strong distrust for the instrument of e-appeals (e-petitions) due to its ineffectiveness as a result of deliberate and unintentional discreditation. Following are the examples of intentional discreditation: submission of essentially similar appeals (petitions) in order to disperse the required number of votes; submission of appeals (petitions) aimed at counter previous appeals (petitions); appeals (petitions) with black PR to fight against political opponents; "trolling" appeals (petitions); etc. Unintentional discreditation is as follows: submission of appeals (petitions) that have already been considered in one form or another; appeals (petitions) submitted to an authority with inappropriate responsibilities, etc.

Given the state of development of civil consciousness in Ukraine, there are issues that can best be addressed at the level of CSOs. Thus, the reduction of trust in the e-petition tool due to the "blurred" number of signatures is carried out by submitting several petitions of different forms but essentially the same content. 
According to the author, in order to eliminate this shortcoming, the publication of an e-petition should be preceded by the following procedures:

- work with the initiators of petitions on the feasibility of creating new ones in the presence of similar collective appeals;

- explaining to the initiators of petitions the most successful forms of their submission (simplicity of wording, clarity of request, etc.);

- analysis of the submitted petitions as to the essence of the issues raised in them;

- combining several petitions into one if they contain essentially the same requirements (proposals).

In order to increase the efficiency of e-appeals (petitions) within state government system, it is expedient to introduce a single state portal with a well-established filtering system and, if an e-petition is successfully met, to send it to a state body responsible for the issues raised. This will allow to:

- compensate for the current low level of civil society awareness of the authorities' powers and responsibilities;

- weaken the level of use of e-democracy tools as a lever in political struggle;

- increase the efficiency of e-democracy tools.

The lack of funding from governmental agencies for such activities should be compensated by CSOs. In this case, it is necessary to use experience of Latvia. E.g., CSOs can provide paid services regarding publishing e-petitions which are openly political lobbying. For example, in Latvia, the cost of placing a petition on the ManaBalls portal for commercial organizations or political parties reaches 4900 Euros (Official site of the Latvian public organization ManaBalss, 2020).

In addition to extra-budgetary funding, civic initiatives should increase civil society political literacy by introducing best global practices. Thus, one of the ways for continuously civil society monitoring of government activities on a certain important issue may be the organization of a number of petitions to stimulate the implementation of a petition. Each of these petitions may contain a request to explain what has been done as a result of a previous petition. 


\section{ANALYSIS OF THE AVAILABILITY OF INDIVIDUAL E-PETITIONS (E-APPEALS)}

The author has analyzed the official web resources of central executive bodies $\left(\mathrm{CEBs}^{2}\right)$ as well as local executive bodies for the availability to citizens of the individual e-petitions' (e-appeals') tool (Figure 2) (Official site of The Cabinet of Ministers of Ukraine, 2020).

One of the main problems is the lack of standards for the availability of the "e-appeals" section and/or the availability of the online form for an e-appeal in this section.

Assesment of the level of the electronic appeals tool's availability on the authorities' official web resources

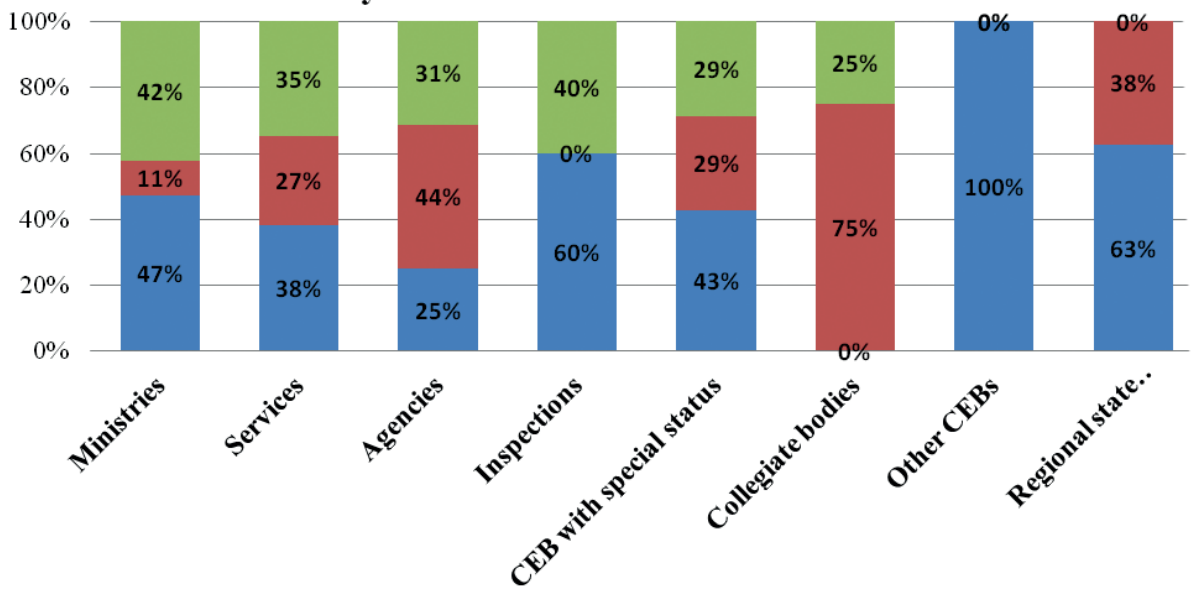

- The web resource contains a section "electronic appeals" and an online form for submitting electronic appeals

- There is no "electronic appeals" section on the web resource

- The web resource contains an "electronic appeals" section, but there is no online form for submitting electronic appeals

Fig. 2. Availability of e-appeals' tool on the official web resources of central and local executive bodies

Source: drawn up by the author

${ }^{2}$ Central and local executive bodies - Government portal www.kmu.gov.ua. 
Disorientation of citizens begins with the fact that the section "e-appeals" on various resources is not placed systematically, namely in different sections, under different names (Citizens' appeals, Internet reception room, For the civil society, Work with citizens, etc.). During the study, it was decided to include the CEBs with either inoperable or absent official web resources in the overall list of portals with no "e-appeals" section.

Another factor that reduces the effectiveness of the tool under consideration is the lack of online submission form. In the best case, sample appeals are provided in MS Word format documents. This does not simplify the submission of e-appeals.

The comparison of the level of availability of the e-appeal tool in Ukraine's authorities reflects the attitude of these bodies to the issue of their proper communication with the civil society. So, the local authorities are more interested in dialogue with citizens than CEBs. The level of accessibility of the use of the e-appeal tool on the official web resources of local authorities is $62 \%$ while for CEBs this indicator is only $38 \%$.

The issue of organizational structure also needs to be regulated in the system of e-appeals. Thus, the above analysis showed that the responsibilities for dealing with e-appeals are assigned mainly to employees who, in addition to working with other forms of appeals (via telephone, hard copies), may be responsible for some other areas of office work, work with archives, consulting civil society, etc.

A positive example of the use of e-appeals (e-petitions) is reflected in the system of interaction between the US government officials and citizens implemented via the citizens' access to any official through his/her page in social networks. For Ukraine, such an experience has its advantages. This approach would increase the effectiveness of e-democracy tools, and its implementation would ensure transparency of civil servants' activities at all levels. Thus, the open publication of appeals (petitions) to civil servants with responses to them should be posted both in social networks of proper officials and on the official web-resource of a proper authority. The information must be open and synchronized with all web-pages of a person. E.g., some Ukrainian CEBs are represented on official web resources of the Facebook social network, including the State Agency for Tourism Development of Ukraine (official web-site of the State Agency for Tourism 
Development of Ukraine, 2020), the State Agency of Ukraine for Arts and Art Education (official web-site of the State Agency of Ukraine for Arts and Art Education, 2020).

\section{SHORTCOMINGS OF THE IMPLEMENTING E-PETITIONS' MECHANISM}

As a result, the paper highlights a number of shortcomings inherent in the mechanism of public administration of the e-democracy tools' implementation in terms of such tools as e-appeals and e-petitions, namely:

- lack of a properly resolved issue of staffing the structural units of central and local executive bodies as well as local governments;

- insufficient level of ensured access of citizens to e-democracy tools;

- lack of legislatively consolidated mechanism of receiving the citizens' e-appeals via the system of personal profiles of public authorities' officials in social networks;

- lack of a unified approach (standard) for the presentation of information on e-appeals and e-petitions on the websites (web portals) of public authorities;

- lack of mechanisms for redirecting appeals (petitions) "bottom-up";

- lack of legal framework to ensure the imperativeness of implementation of appeals (petitions);

- low level of understanding by citizens of the spheres of responsibility and powers of state authorities and officials of various levels;

- lack of mechanisms to counter the efforts of certain political forces, organizational structures, individual politicians and other stakeholders in the use of e-democracy tools to fight politically and discredit these tools. 


\section{RECOMMENDATIONS TO CENTRAL EXECUTIVE BODIES}

The author has developed the following recommendations to central authorities, local governments and CSOs in order to improve the organizational and legal mechanism of public administration of the formation and implementation of instruments of e-democracy (e-petitions):

- to consolidate legislatively the need to periodically improve the legal framework for the use of e-democracy tools;

- to include the issue of ensuring the actualization of the importance of e-democracy tools to improve the interaction between public authorities and the civil society in the Strategy for the Development of the Information Society in Ukraine, the National Strategy for the Promotion of Civil Society in Ukraine;

- to amend the Law of Ukraine "On Citizens' Appeals" regarding the granting to local self-government bodies the right to forward e-petitions to higher authorities in accordance with their powers, ensuring the continued signature gathering regarding the e-petitions;

- to oblige authorities and local self-government bodies to educate citizens on their own powers and areas of responsibility;

- to ensure standardization of interfaces for submitting e-appeals (e-petitions) in order to more effectively use these e-democracy tools;

- to develop and enshrine in law the provision on e-petitions' imperativeness;

- CEBs, local authorities and local self-government bodies should appoint in their structures the units dealing with citizens or individual employees responsible for e-appeals' matters;

- to provide budget funding for accredited CSOs in order to inform citizens on the effectiveness of e-democracy tools, provide them with expert assistance for preparation and promotion of e-petitions, etc. 


\section{CONCLUSIONS}

1. The set of basic legislative acts regarding the formation and realization of e-appeals and e-petitions has been analyzed and systematized.

2. The level of availability of the e-appeal tool on the official Internet portals of central executive bodies and local authorities has been assessed, and ways to resolve existing problems have been suggested.

3. The analysis and generalization of best international practices in realization of tools of e-appeals (e-petitions) has been carried out, and ways to perfect national legislation in this sphere have been offered.

4. The organizational mechanism for the implementation of e-petitions in Ukraine has been improved in terms of cooperation between higher state authorities and local governments, which, in contrast to the existing one, provides for the additional provision of e-appeals from local self-government bodies to higher state authorities, introduction of specialists with relevant legal qualifications to structural units of state bodies, creation of CSOs web portals for civil society assistance regarding the registration and submission of e-appeals (e-petitions), introduction of an official mechanism of paid services for publishing and implementation of e-appeals (e-petitions).

5. The shortcomings inherent in the national mechanism of public administration of the e-appeals and e-petitions instruments' implementation have been highlighted.

6. The recommendations to the public authorities, local governments and civil society organizations on improving e-democracy instruments (e-appeals, e-petitions) have been scientifically substantiated; in particular, to amend current Ukrainian legislation; to include the issues of development of e-appeals (e-petitions) in some strategic and conceptual documents; to expand powers of the Central Executive Bodies and Local Self-government Bodies in terms of improving the implementation of e-appeals (e-petitions), providing 
budget funding for CSOs that increase digital literacy of the population, etc.

Further research will be aimed at studying the information-analytical mechanisms of public administration of the development of e-democracy in Ukraine.

\section{BIBLIOGRAPHY:}

Code of good practice for civil participation in the decision-making process (2009). Downloaded from: https://wcd.coe.int/ViewDoc.jsp?id=1410627.

Concept of e-democracy development in Ukraine. Order of the Cabinet of Ministers of Ukraine, November 8, 2017, No. 797-r. Downloaded from: https://zakon.rada.gov.ua/ laws/show/797-2017-\%D1\%80.

Convention on the Participation of Foreigners in Public Life at Local Level. Council of Europe Convention, November 5, 1992 No. 144. Downloaded from: https://www.coe. $\mathrm{int} / \mathrm{fr} / \mathrm{web} /$ conventions/full-list/-/conventions/rms/090000168007bd26.

Derzhavne ahentstvo rozvytku turyzmu Ukrainy [State Agency for Tourism Development of Ukraine] (2020). Official site of State Agency for Tourism Development of Ukraine. Downloaded from: https://www.facebook.com/DARTUkraine/.

Derzhavne ahentstvo Ukrainy z pytan mystetstv ta mystetskoi osvity [State Agency of Ukraine for Arts and Art Education] (2020). Official site of State Agency of Ukraine for Arts and Art Education. Downloaded from: https://www.facebook.com/ державне-агентство-України-з-питань-мистецтв-та-мистецької-освіти-100654 368309198/.

Kabinet Ministriv Ukrainy. Orhany vykonavchoi vlady [The Cabinet of Ministers of Ukraine. Executives Bodies] (2020). Official site of The Cabinet of Ministers of Ukraine. Downloaded from: https://www.kmu.gov.ua/catalog.

Kabinet Ministriv Ukrainy. Petytsii [The Cabinet of Ministers of Ukraine/ Petitions] (2020). Official site of The Cabinet of Ministers of Ukraine. Downloaded from: https://petition.kmu.gov.ua/.

Official site of the Latvian public organization ManaBalss. Retrieved from https://manabalss.lv/.

On Access to Public Information. Law of Ukraine, Jan 13, 2011, No. 2939-VI. Downloaded from: https://zakon.rada.gov.ua/laws/show/2939-17.

On Citizens' Appeals. Law of Ukraine, Oct 02, 1996, No. 393/96-BP. Downloaded from: https://zakon.rada.gov.ua/laws/show/393/96-вр. 
Prezydent Ukrainy. Petytsii [The President of Ukraine. Petitions] (2020). Official site of The President of Ukraine. Downloaded from: https://petition.president.gov.ua/.

The official website of Finland's petitions. Retrieved from https://www.kansalaisaloite. fi/fi.

The UK Parliament petitions website (e-petitions). Downloaded from: https://www. gopetition.com/.

Recommendation CM/Rec (2001)19 of the Committee of Ministers to member states on the participation of citizens in local public life. Council of Europe Recommendation, December 6, 2001. Downloaded from: https://rm.coe.int/16804f513c.

Recommendation CM/Rec (2009) 1 of the Committee of Ministers to member states on electronic democracy (e-democracy). Downloaded from: https://wcd.coe.int/ViewDoc.jsp?id=1410627.

Verkhovna Rada Ukrainy. Petytsii [The Verkhovna Rada Ukrainy. Petitions] (2020). Official site of The Verkhovna Rada of Ukraine. Ukrainian parliament. Downloaded from: https://itd.rada.gov.ua/services/Petitions/. 